
Digitized by the Internet Archive in 2011 with funding from University of Toronto 






\section{CONTRIBUTIONS OF THE ROYAL ONTARIO MUSEUM OF ZOOLOGY}

No. 20 : THE BLATTARIA AND ORTHOPTERA OF ESSEX COUNTY, ONTARIO. By F. A. URQUHART. 



\title{
THE BLATTARIA AND ORTHOPTERA \\ OF ESSEX COUNTY, ONTARIO
}

\author{
By F. A. Urquhart
}

\section{Essex County}

Climate and Life Zone: The climate of this region is tempered by the presence of the lower Great Lakes; winters are comparatively mild and the growing season is long (Putnam and Chapman, 1938). These features favour southern species in establishing themselves. The rather limited stretches of forest areas are composed, for the most part, of lofty hardwoods. The black walnut (Juglans nigra) is one of the most conspicuous; other trees such as the chestnut oak (Quercus montana), hackberry (Celtis occidentalis), shagbark hickory (Carya ovata), red cedar (Juniperus virginiana), papaw (Asimina triloba), and magnolia (Magnolia acuminata) occur in varying degrees of abundance. Of the smaller plants possibly the most outstanding is the prickly pear (Opuntia rafinesquii) which is found only in the most southern part of Ontario. The presence of such plants as these makes it apparent that Essex County can rightly be regarded as within the Carolinian area of the Austral Life Zone (Merriam, 1893, '94, '98).

Physiographic and Ecological Features: The whole of Essex County is low-lying and flat with numerous extensive marsh areas. The soil is composed almost entirely of sand, with occasional fields of dark loam, probably marking the location of former marshes. The creeks and streams, which are rather sluggish, meander across level fields and through shallow ravines. Their paths are often marked by numerous marshes that support a dense growth of grasses, sedges and rushes. Most of the land areas are devoted to agriculture. Occasionally a small clump of trees, marking the remains of a hardwood forest, may be seen, but such woodlots are usually grazed. Fortunately a few small stretches of woodland, which still remain in their natural condition, exist in the vicinity of Point Pelee.

Since the soil of Essex County is composed almost entirely of sand, one would expect to find rather extensive beaches along the shores of the lakes and rivers, but such areas are relatively scarce. Of the localities where collections were made along the shores of Lake St. Clair only one boasts of a small beach and this is cluttered with summer cottages and man-made structures of all sorts. Local- 
ities which are free from such disfigurements consist for the most part of grasslands which extend to within a few feet of the shore. The remainder of the shore-line is made up of wave-washed sand or marsh areas. The only localities where extensive beaches occur are along the east and west shore of Point Pelee and portions of the north shore of Lake Erie. The east shore of Point Pelee consists of a continuous sand-dune. This situation proved the most fruitful for the collecting of species of grasshoppers which inhabit sand areas. The average width of this shore-dune is approximately a hundred yards and, since it is low-lying, the waves often wash completely over it into the marsh beyond.

The scarcity of dry, grassy hill-sides and shrubby areas notably limits the number of species of short-horned grasshoppers. Most of the species taken inhabited rather damp situations such as meadows and the marginal areas of the marshes. Of the species of Orthoptera collected, those belonging to the Conocephalinae were most abundant. Nearly every pasture and roadside ditch fairly teemed with Conocephalus. Second to Conocephalus in point of abundance was the red-legged locust, Melanoplus femur-rubrum, a species that occurred in greatest numbers in low-lying, damp pastures and at the margins of the numerous marshes and creeks. Melanoplus bivittatus was also of common occurrence throughout this locality although not nearly as abundant as femur-rubrum. In the drier pastures, especially those used for cattle grazing, Orphulella speciosa was commonly found, together with Melanoplus mexicanus, Dissosteira carolina, and Encoptolophus sordidus. Not a single specimen of Camnula pellucida, a common species in most parts of southern Ontario, was taken during this expedition; it is included in the present work on the basis of a single record from Point Pelee (Walker, 1902).

We have in the occurrence of the mole-cricket (Gryllotalpa hexadactyla) striking evidence of the austral aspect of the Point Pelee Saltatorial fauna; this species occurs in rather humid soil usually along the margins of creeks and in company with Tridactylus apicalis. Other typically southern forms found were, Paroxya hoosieri, Metaleptea brevicornis, and Pseudopomala brachyptera. In wooded areas Nemobius maculatus was abundant while in the dense, leafy branches of the tall walnuts and oaks Pterophylla camellifolia was of common occurrence in late summer in the wooded areas of Point Pelee. Trimerotropis maritima interior was found upon the sand dunes of Point Pelee and occasionally on small sand areas bordering Lake St. Clair. This species was also exceptionally abundant in sandy, cultivated fields in Point Pelee. 


\section{Habitats OF Orthoptera}

As previously mentioned, Essex County is low-lying; there are relatively few grassy hillsides and no areas of bare rock. Small, sluggish creeks bordered by a rich growth of grasses and sedges, connect the numerous marsh areas; the latter occupy the greater part of the base of Point Pelee. Although the ditches, along the margins of roadways, are fairly shallow they contain a sufficient amount of water throughout the summer to support aquatic vegetation. Forest areas have been depleted or reduced to small woodlots; the only extensive areas of virgin forests are located in Point Pelee. Extensive sand areas are found along the Lake Erie shore, as well as sandy cultivated land in the interior. Dry, grassy areas are limited to pastures or margins of woodlots.

Sand Areas: Along the east and west shores of Point Pelee there are rather extensive sand dunes that support a somewhat meagre flora of which panic grass (Panicum virgatum), beard grass (Andropogon scoparius), Russian thistle (Salsola kali) and cocklebur (Xanthium echinatum) are the most abundant species present.

Of the grasshopper fauna, the most abundant and characteristic species is the "inland seaside locust" (Trimerotropis maritima interior). Other species, such as Dissosteira carolina, Melanoplus mexicanus, and Encoptolophus sordidus are found in limited numbers.

Sandy stretches of land, resulting from fields that have been plowed over for agricultural purposes, also occur inland. The grasshoppers found in such areas are much the same as those found on the sand dunes.

Marsh Areas: As previously mentioned, marsh areas are of common occurrence throughout Essex County. The most abundant plant present in such marsh areas is the "blue-jointed grass" (Calamagrostis canadensis); certain of the smaller marshes contain a luxuriant growth of the "river-bank sedge" (Carex riparia), especially in low-lying areas along the margins of creeks.

By far the greatest number of species and individuals of Saltatoria were found in the marshes. This may be due to the fact that such areas have remained in their natural conditions throughout the past history of Essex County while the dry land areas have been subjected to drastic changes; or it may be owing to the presence of a luxuriant vegetation.

The grasshoppers found in the marsh are, for the most part, members of the Tettigoniidae. Conocephalus fasciatus was found to be most abundant; $C$. attenuatus was of common occurrence in 
most marsh areas and abundant in a rather extensive marsh located near Malden Centre.

In addition to the long-horned grasshoppers, a few species of Acridinae were of common occurrence; Metaleptea brevicornis in a small marsh near Arner; Chorthippus longicornis in the shorter grass at the margins of the marshes; and Stethophyma lineatum in small marsh areas at the base of Point Pelee.

The margin of the marsh presents a somewhat different flora and fauna from that of the marsh proper or the drier land areas. Certain plants, such as species of Solidago, that do not occur in the marsh, may flourish along the margins. The species of Orthoptera found along the margin are also different or, in some cases, more abundant than those found in the marsh. Acrydium subulatum and Paratettix cucullatus are of common occurrence on the humid, mud flats while Melanoplus bivittatus and M. femur-rubrum are usually abundant in the rather dense vegetation.

Grasslands: There are few natural grasslands in Esssex County. Most of the lands approaching this type of habitat are devoted to cattle grazing and, periodically, such lands are placed under cultivation.

A typical pasture field may be divided into three sections: short-cropped grass area; (2) shrubby area; (3) humid area of long grass. In the areas of the field where the grass has been cut short by grazing cattle, Nemobius fasciatus, Orphulella speciosa, Melanoplus mexicanus, Dissosteira carolina and Spharagemon bolli are abundant. In shrubby areas, such as along the edges of fence rows or the margins of woodlots where there is a dense growth of tall herbs and shrubs, long-horned grasshoppers appear to be predominant; Conocephalus fasciatus is usually most abundant together with smaller numbers of Conocephalus strictus. Melanoplus femur-rubrum is usually found in numbers in such a habitat as well as the oblong-winged katydid (Amblycorypha oblongifolia). Conocephalus brevipennis, Orchelium vulgare and $O$. gladiator are usually associated with the tall grasses growing in the more humid portions of the field. Acrydium ornatum and Acrydium subulatum are of common occurrence on the humid soil.

Wooded Areas: Since most of the wooded areas of Essex County have been cleared for agriculture, only a few isolated natural forest areas are to be found. Those remaining are almost entirely composed of deciduous trees; black walnut (Juglans nigra) is the most conspicuous tree in this region; other trees such as the chestnut oak 
(Quercus montana), red oak (Quercus borealis), hackberry (Celtis occidentalis), and sassafras (Sassafras officinalis) are of common occurrence.

As compared with the other habitats, the wooded areas contain relatively few species of Saltatoria. Those that are present usually secrete themselves beneath the litter of the forest floor. Ceuthophilus meridionalis may be found beneath the loose bark of fallen trees and in the crevices of decaying logs. Two species of small ground crickets, Nemobius maculatus and N. carolinus, may be seen in numbers scurrying over the leaf-strewn floor. The true katydid (Pterophylla camellifolia) may be heard stridulating in the foliage of the trees. In the thick underbrush Scudderia furcata and Amblycorypha oblongifolia are of common occurrence. In the more humid portions of the woods, especially in those sections where the land is flooded in early spring, grouse locusts, such as Acrydium subulatum and Acrydium arenosum are usually present.

In the open clearings of the woods a number of species characteristic of the field habitat may occur, such as: Oecanthus niveus, Gryllulus assimilis, Nemobius fasciatus, Conocephalus brevipennis and C. fasciatus.

\section{LiTERATURE}

The records of various species of Orthoptera found in Essex County have been considered in the works of Dr. E. M. Walker $(1898,1899,1901,1902,1902 a, 1904,1904 a, 1905,1912)$ on the Orthoptera of Ontario.

Recently, Walker and Urquhart (1940) published a list of additional records of Ontario Orthoptera, a number of which were taken in Essex County; and a short article has been published on the occurrence of Schistocerca americana in Essex County (Urquhart, 1939).

Most of Walker's records on the Ontario Orthoptera are included in Blatchley's Orthoptera of North-eastern America (1920).

\section{System of Classification}

Many of the American Orthopterists have considered the Orthoptera as an order comprising, in addition to others, such families as the cockroaches (Blattidae), mantids (Mantidae), and phasmids (Phasmidae). However, as has been pointed out by various authors, such families are sufficiently distinct to warrant a higher ranking.

In a recent publication, Zeuner (1939), in his chapter devoted to the phylogeny of the orthopteroid order, has presented the fol- 
lowing classification of the various orders considered in this present paper based on "Handlirch's latest views".

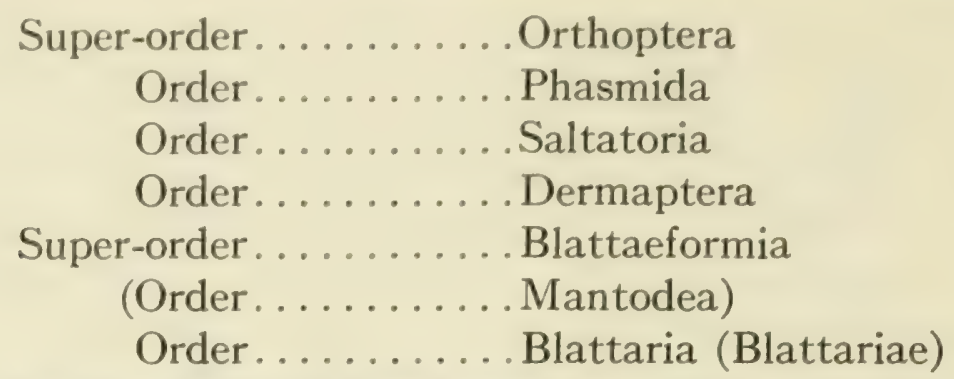

This classification, which is based upon a careful study of present and past forms of orthopteroid insects, has been adopted by the writer.

Ander (1939a) has made a rather exhaustive study of the order Saltatoria and has proposed the following classification:

\begin{tabular}{|c|c|}
\hline Ord & atoria \\
\hline Suborder..... & Ensifera \\
\hline Superfamily & Grylloidea \\
\hline Family... & Gryllotalpidae \\
\hline Family... & Gryllidae \\
\hline Subfami & Oecanthinae \\
\hline Subfami & Trigonidiinae \\
\hline Subfami & Nemobiinae \\
\hline Subfami & Gryllinae \\
\hline Superfamily & Tettigonioidea \\
\hline Family... & Gryllacrididae \\
\hline Subfam & $\begin{array}{l}\text { Rhaphidophorinae } \\
\text { (Fam. Rhaphidophoridae) }\end{array}$ \\
\hline Family. . & Tettigoniidae \\
\hline Subfam & Pseudophyllinae \\
\hline Subfami & Decticinae \\
\hline Subfami & Conocephalinae \\
\hline Subfami & Copiphorinae \\
\hline Subfami & Phaneropterinae \\
\hline Suborder..... & Caelifera \\
\hline Superfamily & Tridactyloidea \\
\hline Family. . & Tridactylidae \\
\hline Superfamily & Acridoidea \\
\hline Family... & Acrydiidae \\
\hline Family... & Acrididae \\
\hline
\end{tabular}

The above classification has been followed in the present paper and is the same as that suggested by Ander with the exception of 
placing the Rhaphidophorinae as a subfamily of the Gryllacrididae instead of a family, Rhaphidophoridae. This latter change is in accord with the work of Karny (1910) and has been adopted by Hubbell (1936).

\section{MATERIAL}

The present paper is based upon a collection of approximately 5,000 specimens and numerous field observations made by the writer during the summer of 1938, together with specimens collected by Dr. E. M. Walker and various members of the staff of the Royal Ontario Museum of Zoology. This complete collection is now contained in the latter institution.

\section{Localities}

The accompanying map (fig. 1) gives the localities in Essex County, together with indications of the habitats, from which specimens were obtained.

\section{BLATTAEFORMIA}

\section{BLATTARIA}

This order is represented in Essex County by four species, each belonging to a separate genus; only one of the species is native to this locality.

\section{BLATTIDAE}

Blattinae

\section{Blatta Linnaeus}

\section{$B$. orientalis Linnaeus}

Like Blattella germanica, this introduced species is a household pest throughout the settled parts of Southern Ontario.

Mr. W. R. Lapp of the Department of Agriculture, Windsor, Ontario, reports a specimen taken in Windsor on September 26, 1938 ; it is quite likely that this large, dark-coloured species occurs in certain dwellings throughout Essex County.

\section{PSEudomopinae \\ Parcoblatta Hebard}

$P$. fulvescens (Saussure and Zehnter)

Hebard, to whom specimens of this cockroach were sent for identification, stated that they were possibly adventive from the southern United States. I am inclined to believe, however, that, since ten specimens were taken on the same day and in the same locality and two specimens as far north as Go Home Bay, Georgian 


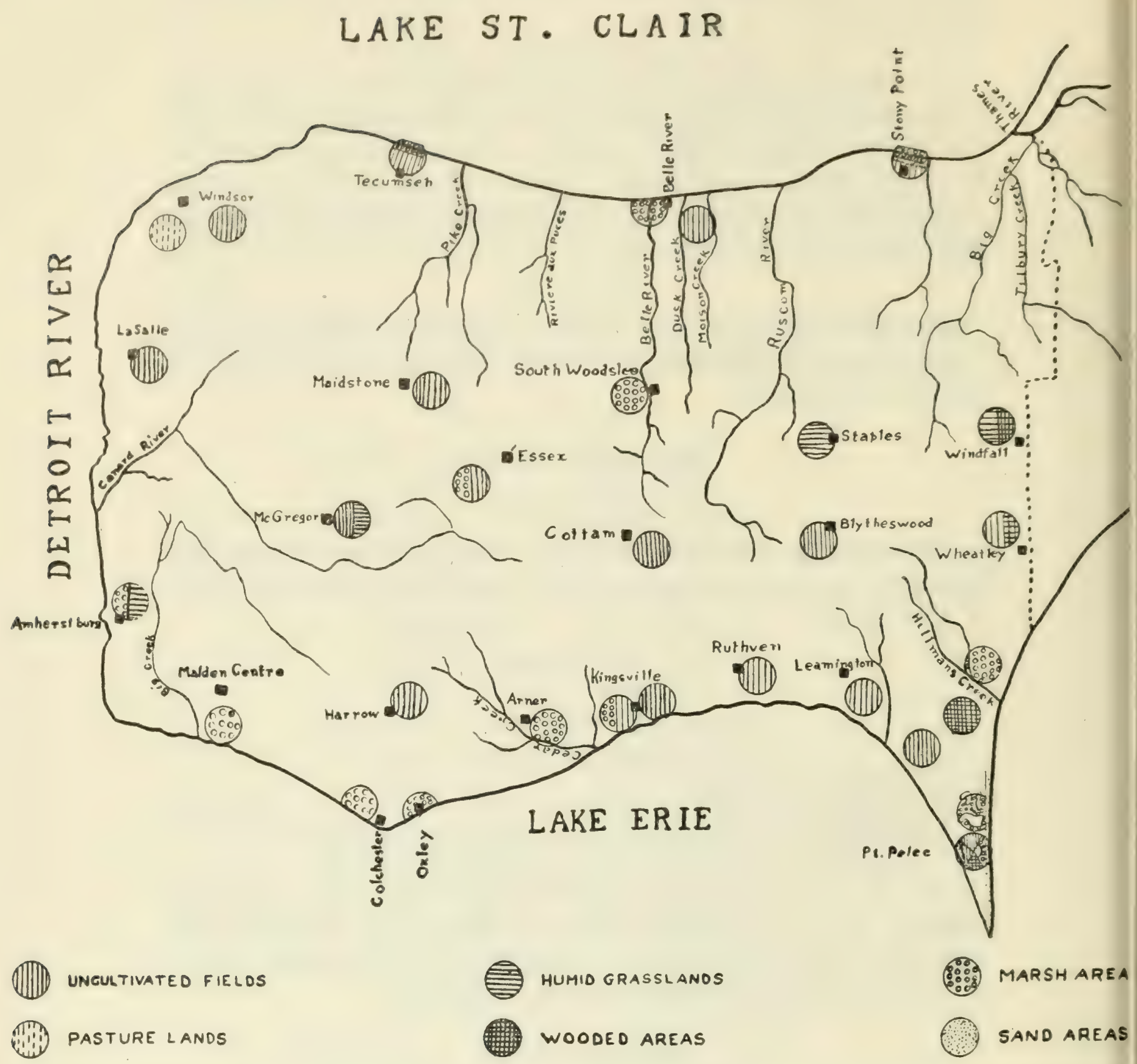

Figure 1.-Outline map of Essex County showing the localities and types of habitats from which collections were obtained. 
Bay, that this species is native to Ontario in certain suitable localities.

Pornt Pelee: July 18, 1920, $10 \sigma^{7} \sigma^{7}$, Bigelow; June 21, 1920, $1 \sigma^{7}$, Logier.

\section{$P$. pennsylvanica (De Geer)}

This species is of common occurrence throughout Essex County, inhabiting wooded areas where it seeks protection beneath the loose bark of trees, fallen logs and other surface debris. Both nymphs and adults hibernate and may be found from early spring until late fall.

Point Pelee: June 12, $3 \sigma^{x} \sigma^{7}, 2$ \& $~ \&, 1$ nymph; Aug. 28, $1 \sigma^{x}$; Sept. 1, 4 nymphs; Sept. 8, $1 \sigma^{7}$; Sept. 21, 1 nymph; 1938; June 21, 1920, $7 \sigma^{7} \sigma^{7}, 7$ \& \&, Logier; June 13, 1920, $5 \sigma^{7} \sigma^{7}, 5$ ㅇ ㅇ , Bigelow; May 20, 1934, $1 \sigma^{x}, 4$ nymphs, Ide.

B. germanica (Linnaeus)

\section{Blattella Caudell}

This species is a household pest throughout Southern Ontario. W. R. Lapp informs me that it abounds throughout the district.

\section{ORTHOPTERA}

\section{DERMAPTERA}

In Ontario this order is represented by a single native species belonging to the family Forficulidae. It is quite possible that Forficula auricularia and Labia minor may occur in parts of Essex County but there are no records of these species from this locality.

\section{FORFICULIDAE}

\section{Doru Burr}

\section{D. aculeatum aculeatum (Scudder)}

This species is apparently limited to the more southern parts of Essex County where it may be found among the tall grasses growing along the margins of marshes and creeks, or beneath leaves, sticks and other surface debris.

Arner: Aug. 19, 1938, 1 \%. Point Pelee: May 20, 1934, 1 , Ide.

\section{D. femorata (Say)}

\section{PHASMIDA}

PHASMIDAE

Diapheromera Gray

This insect is abundant throughout Essex County; far more abundant than the single record might indicate.

Point PeleE: Sept. 13, 1938, 1 ơ'$^{\text {'. }}$ 


\section{SALTATORIA}

\section{ENSIFERA}

\section{GRYLLOIDEA}

\section{Gryllotalpidae}

\section{Gryllotalpa Latreille}

\section{G. hexadactyla Perty}

The mole-cricket is apparently limited to the southern parts of Essex County, especially in the vicinity of Point Pelee, where it may be said to be quite abundant. The following record of captures does not give a clear indication of its abundance since, being subterranean in habit, specimens were difficult to capture.

This species has been recorded previously from Leamington by Fletcher (1892) and repeated by Walker (1904).

Point Pelee: June 23, 1920, $4 \sigma^{7} \sigma^{7}$, Bigelow; June 27, 1920, 1 nymph, Walker; July $23,1938,3 \sigma^{x} \sigma^{x}, 2$ nymphs.

\section{GRYLLIDAE}

\section{Oecanthinae}

\section{Oecanthus Serville}

\section{O. nigricornis $\mathrm{F}$. Walker}

In the present paper Oecanthus nigricornis nigricornis and $O$. nigricornis quadripunctatus have been considered under Oecanthus nigricornis.

It is not possible to distinguish nigricornis nigricornis from nigricornis quadripunctatus, in so far as the specimens taken in Essex County are concerned. The marks on the two basal joints of the antennae vary from those typical of quadripunctatus to almost solid black; and the same applies to the amount of pigmentation on the pronotum (see fig. 2). Fulton (1926), however, is of the opinion that "in the eastern portion of the United States and Canada nigricornis and quadripunctatus are fairly distinct, sufficiently so to be considered different species if they did not range beyond this region". In so far as the choice of habitat is concerned, no difference was observed between these two forms, although Fulton has pointed out a difference in the choice of host plants during oviposition; of the specimens considered in the present paper, typical nigricornis and quadripunctatus were found in the same field and inhabiting the 
same kind of vegetation. Fulton has, however, pointed out certain differences in the structure of the eggs which may indicate a distinctive feature between the two extreme of nigricornis.

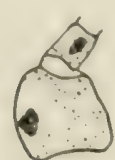

a

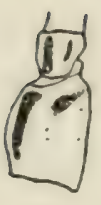

e
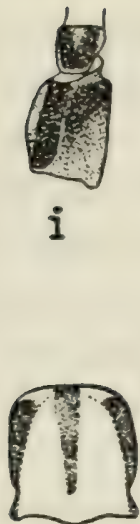

m

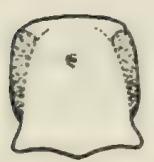

q
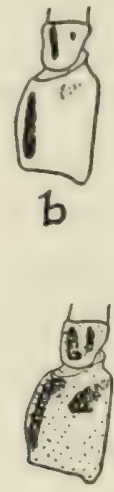

f
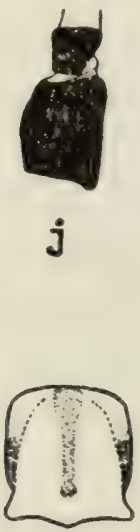

n

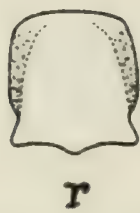

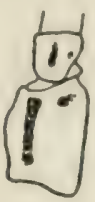

c

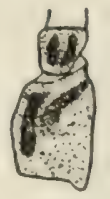

g
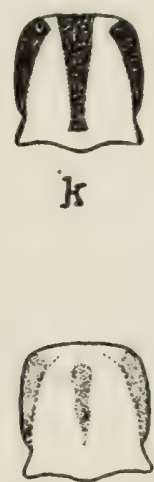

o

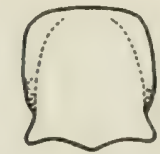

s
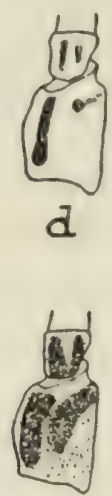

乃
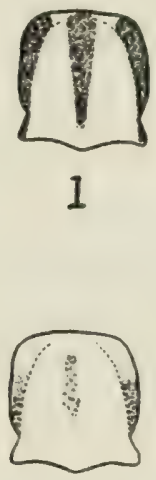

p

FIGURE 2.-Basal segments of the antennae of Oecanthus showing the black markings. a, O. niveus; $b-j, O$, nigricornis showing variations in the amount of pigmentation; $\mathrm{k}-\mathrm{s}$, dorsal view of pronotum of $O$. nigricornis showing variations in the amount of pigmentation.

Rehn and Hebard (1916) point out that O. nigricornis may be distinguished from other species by the heavier pronotum of which the width approximates the length; in quadripunctatus the pronotum is not quite as wide. From measurements of the length and width of the pronotum of seventy-seven specimens of typical quadri- 
punctatus, sixty specimens of typical nigricornis, and seventeen intermediate specimens, the following results were obtained:

quadripunctatus: Male: length, 1.9-2.4 mm.; width, 1.9-2.4 mm.

Female: length, 2.1-2.8 mm.; width, 1.9-2.4 mm.

nigricornis: Male: length, 2.0-2.7 mm.; width, 2.0-2.7 $\mathrm{mm}$.

Female: length, 2.1-2.8 mm.; width, 1.9-2.4 mm.

intermediate: Male: length, 2.3-2.6 mm.; width, 2.0-2.8 $\mathrm{mm}$.

Female: length, 2.2-2.8 mm.; width, 1.9-2.4 $\mathrm{mm}$.

From these measurements it is seen that the pronotum of nigricornis is apparently "heavier" than that of quadripunctatus but the difference is very slight and there are many specimens of both forms with identical measurements and therefore such a character is of little diagnostic significance.

This species was found to be exceptionally abundant throughout Essex County. In one particular field, that had been allowed to "grow wild" and hence contained a rather dense growth of tall grasses, small shrubs and goldenrod, as many as twenty-six specimens of $O$. nigricornis were taken with one sweep of the insect net. A number of complaints were received from the farmers concerning the prevalence of $O$. nigricornis in tobacco crops; this usually occurred when the latter were in proximity to a field such as the above. Specimens were also taken in grassy areas bordering woodlots, margins of marshes and roadways, and in the foliage of walnut and oak trees.

A series of 381 specimens was obtained, representing all of the localities of Essex County considered in this paper.

\section{O. niveus (De Geer)}

This species is not nearly as abundant as nigricornis. It was found in dry, shrubby areas, especially among cultivated raspberry bushes and the like, in sandy fields. Although Walker (1904) is of the opinion that $O$. nigricornis is more abundant on raspberry bushes than is $O$. niveus, it was the author's experience to find the former species in grassy areas such as pastures and the like, while $O$. niveus was not taken in such areas. However, at Brockville, Ont., O. nigricornis was found to be exceptionally abundant in a field devoted to the cultivation of raspberry bushes which would confirm Walker's contention.

Leamington: Aug. 7, 1901. Arner: Aug. 9, 1901; Walker (1904). Point Pelee: July 27, $1 \sigma^{\Im}$; Aug. 10, $3 \sigma^{\top 7} \sigma^{\top}, 1$ \% 1938. 


\section{TRIGONIDIINAE}

\section{A. exigua (Say)}

\section{Anaxipha Saussure}

This small, marsh-inhabiting cricket seems to be confined to the more southern portions of Essex County. In certain marsh areas it was found in considerable numbers (Walker and Urquhart, 1940). Point Pelee: Sept. 8, 29 \%; Sept. $15,1 \%$; 1938. Malden Centre: Aug. 12, 1938,1 \%.

\section{NeMOBIINAE}

Nemobius Serville

\section{N. carolinus carolinus Scudder}

Abundant throughout Essex County in wooded areas where it may be found running over the dry leaves of the forest floor or hiding beneath loose bark, fallen logs and other surface debris.

Point Pelee: Aug. 28, $10 \sigma^{7} \sigma^{7}, 9$ \% $\%, 8$ nymphs; Sept. $8,3 \sigma^{7} \sigma^{7}, 12$ \% $\%$; Sept. 9 ,

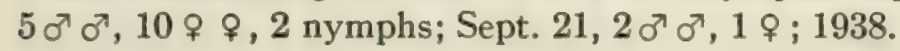

\section{N. maculatus Blatchley}

This species is quite abundant in the more southern parts of Essex County, especially in the vicinity of Point Pelee where it may be found in considerable numbers in wooded areas (Walker and Urquhart, 1940).

Point Pelee: Aug. $8,70^{7} \sigma^{7}, 4$ \% $~, 4$ nymphs; Sept. 8, $16 \sigma^{7} \sigma^{7}, 18$ \% $\subsetneq$; Sept. 25, $6 \sigma^{77} o^{7}, 3$ ㅇ ㅇ; 1938.

\section{$N$. griseus griseus E. M. Walker}

Since this species has been taken by Walker (1904) at Toronto, Sarnia, and Lake Simcoe, Ont., and by the writer as far north as Mactier, Ont., it probably occurs in dry, sandy areas of Essex County.

\section{N. fasciatus fasciatus (De Geer)}

This is one of the most abundant species of Saltatoria, inhabiting pastures and the like, throughout Essex County.

Previously reported from Point Pelee and Arner by Walker (1904).

Point Pelee: July 24, 1 nymph; Aug. $3,4 \sigma^{7} \sigma^{7}$; Aug. 7, $6 \sigma^{7} \sigma^{7}, 5$ $\%$, 8 nymphs; Aug. 8, $3 \sigma^{7} \sigma^{7}, 2$ \% ㅇ; Aug. 12, $7 \sigma^{7} \sigma^{7}, 13$ 우, 5 nymphs; Aug. 13, 2 우; Aug. 16, $4 \sigma^{7} \sigma^{7}, 5$ 우 우; Aug. 17, $2 \sigma^{7} \sigma^{7}, 2$ 우 우 ; Aug. 23, $10 \sigma^{7} \sigma^{7}, 6$ 우 우; Aug. 24, 4 우 우; Aug. 28, 1 ㅇ ; Sept. 8, $2 \sigma^{7} \sigma^{7}, 4$ ㅇ ㅇ ; Sept. 14, $1 \sigma^{7}$; Sept. 23, $2 \sigma^{7} \sigma^{\top}, 1$ \% ; 1938. Leamington: Sept. 15, 1938, $5 \sigma^{7} \sigma^{7}, 9$ \% 3 ㅇ. MaIdstone: Sept. 27, 1938, $1 \sigma^{7}$. Harrow: Sept. 26, 1938, 1 \% 
South Woodslee: Sept. 27, 1938, 1 . Windsor: Aug. 25, 1938, $3 \sigma^{7} \sigma^{7}, 2$ 2 . Belle River: Aug. 27, 1938, 1 $\%$. Essex: Aug. 31, 1938, $2 \sigma^{7} \sigma^{7}, 6$ 우 Arner: Sept. 5, $10^{7}$; Aug. 12, $10^{7}, 1$ nymph; 1938. Wheatley: Sept. 25, 1938, $10^{7}, 1$ nymph.

\section{N. fasciatus socius (Scudder)}

Whereas $N$.f. fasciatus is usually found on rather dry grasslands, $N$. f. socius occurs at the margins of marshes. Since it occurs in quite a number of localities in Southern Ontario, extending as far north as Bracebridge, Ont., and abundantly at the margins of marshes from Toronto east to Summerstown, Ont.(Urquhart, 1941), it undoubtedly occurs throughout Essex County in similar situations.

Point Pelee: Aug. 12, $1 \%$; Aug. 23, $2 \%$; 1938. Wheatley: Sept. 25, 1938,1 ㅇ․

\section{GRYLLINAE}

\section{Gryllulus Uvarov}

By a decision of the International Commission on Zoological Nomenclature (1928) Gryllus campestris Linnaeus was made the type of the genus Gryllus Linnaeus. The latter name had been generally applied to those species which are now placed under the genus Gryllulus Uvarov. The name Liogryllus Saussure, formerly used for Gryllus campestris-group, has become a synonym of Gryllus Linnaeus. The genotype of Gryllulus is Gryllus domesticus Linnaeus.

\section{G. domesticus Linnaeus}

Since this species has become a household pest of considerable importance in most of the settled parts of Southern Ontario, it may be assumed that it does occur in Essex County, although we were unable to obtain any reports of its occurrence in this locality.

\section{G. assimilis Fabricius}

The two forms, G. a.luctuosus and G. a. pennsylvanicus, are here considered under G.assimilis. From material obtained in the course of this investigation it was found that while the two forms are physiologically distinct, they differ morphologically only in so far as the length of the female ovipositors are concerned (manuscript).

Both G. assimilis luctuosus and G. a. pennsylvanicus are of common occurrence throughout Essex County. The former is abundant in pastures and roadsides in late summer while the latter is usually found in the proximity of woods in spring and early summer. 
G. a. luctuosus has been recorded from Point Pelee by Walker (1904).

Point Pelee: Aug. 7, 1901, $3 \sigma^{7} \sigma^{7}, 3 \%$ 으, Walker; Aug. 7, $3 \sigma^{7} \sigma^{7}, 9$ nymphs; Aug. 8, 1 nymph; Aug. 12, 1 nymph; Aug. 23, 1 \%; Aug. 24, 1 nymph; Sept. 8, $1 \sigma^{7}, 1$; Sept. 22, $115 \sigma^{7} \sigma^{7}, 127$ \% ; Sept. $16,1 \sigma^{7} ; 1938$. Wheatley: Sept. 25, 1\%. Windfall: Sept. 25, 1 \% South Woodslee: Sept. 27, 1938, 1 . CotтAм: Sept. 27, 1938, 1 ㅇ․

\title{
TETTIGONIOIDEA
}

\section{GRYLLACRIDIDAE}

\section{RHAPHIDOPHORINAE}

C. maculatus (Harris)

\section{Ceuthophilus Scudder}

This species inhabits wooded areas, secreting itself beneath the loose bark of trees or under fallen logs and the like.

Point Pelee: July 25, $2 \sigma^{7} \sigma^{7}, 1$; ; Aug. 2, $1 \sigma^{7}$; 1920; Bigelow.

\section{C. meridionalis Scudder}

This large species inhabits the same situations as $C$. maculatus. Pornt Pelee: July 12, 1 \%; July $20,1 \sigma^{7}, 1$ \% July $25,2 \sigma^{7} \sigma^{7}, 3$ ㅇ $q$; 1920 ; Bigelow; June 28, 3 nymphs; July $23,2 \sigma^{7} \sigma^{7}, 3$ ㅇ क; July $31,1 \sigma^{7}, 1$ \% ; Sept. 21, $10^{7}, 3$ \% $\% ; 1938$.

\section{TETTIGONIIDAE}

Pseudophyllinae

P. camellifolia (Fabricius)

\section{Pterophylla Kirby}

This species is apparently limited to the more southern parts of Essex County. It was fairly abundant in the vicinity of Point Pelee in late summer but, since it inhabited the dense foliage of tall walnut trees, there was some difficulty in capturing specimens and hence only two are here recorded.

This species has been previously recorded from Point Pelee by Walker and Urquhart (1940).

Point Pelee: Aug. 22, $1 \sigma^{\top}$; Sept. 7, $1 \sigma^{7} ; 1938$.

\author{
Decticinae \\ Atlanticus Scudder \\ A. testaceus (Scudder) \\ This species was first reported by Walker (1905) as Atlanticus \\ pachymerus Burm. Walker states that the specimens were "found \\ in the more open parts of a dry upland wood consisting chiefly of \\ oak and other hardwoods". \\ ARNER: Aug. 9, 1901, $2 \sigma^{\nearrow} \sigma^{\nearrow}, 1$ \% ; Walker.
}




\section{Conocephalinae}

\section{Orchelimum Serville}

\section{O. nigripes Scudder}

This handsome grasshopper is common throughout Essex County, inhabiting marsh areas, for the most part; it is also common in meadows of long grass as well as the margins of wooded areas.

This species has been previously recorded from Point Pelee by Walker (1905).

Point Pelee: Aug. 8, 1 nymph; Aug. 10, $2 \sigma^{7} \sigma^{7}$; Aug. 16, $1 \sigma^{7}$; Aug. 17, 2 nymphs; Aug. 18, $4 \sigma^{7} \sigma^{7}$; Aug. 23, 1 \% , 1 nymph; Aug. 24, 2 \% ㅇ, 1 nymph; Aug. 28, $8 \sigma^{7} \sigma^{7}$ 4 우 우; Aug. 30, $1 \sigma^{7}$; Sept. 2, $1 \sigma^{7}, 4$ 우 우, 2 nymphs; Sept. 8, $23 \sigma^{7} \sigma^{7}, 13$ 우 우 ;

Sept. 14, $2 \sigma^{7} \sigma^{7}$; Sept. 15, $2 \sigma^{7} \sigma^{7}$; Sept. 16, 2 \% \% Sept. 23, $2 \sigma^{7} \sigma^{7}$; 1938. LeAMington: Sept. 15, 1938, $1 \sigma^{7}$. Essex: Aug. 31, 1938, $3 \sigma^{\pi} \sigma^{7}, 3 \%$ 우. Arner: Aug. 12, 1938, $9 \sigma^{\top} \sigma^{\top}, 8 \%$ ㅇ , 49 nymphs. Oxley: Sept. 26, 1938, 1 \%. CQlChester: Sept. 26, 1938, 1 ㅇ. Malden Centre: Aug. 19, 1938, $2 \sigma^{7} \sigma^{7}, 1$.

\section{O. vulgare Harris}

This is the most abundant and ubiquitous species of Orchelimum. It is found throughout Essex County, inhabiting open, grassy fields of a humid nature as well as marsh areas.

Walker (1905) has previously recorded this species from Arner and Point Pelee.

Point Pelee: Aug. 7, 1901, $1 \sigma^{7}$, Walker; July 22, $10^{7}$; July 24, 2 nymphs; July $27,5 \sigma^{7} \sigma^{7}$; Aug. 1, $1 \sigma^{7}$; Aug. 6, $2 \sigma^{7} \sigma^{7}, 1$ nymph; Aug. 8, $1 \sigma^{7}$; Aug. $9,3 \sigma^{7} \sigma^{7}$; Aug. 10, $3 \sigma^{7} \sigma^{7}$; Aug. 12, $3 \sigma^{7} \sigma^{7}$; Aug. 13, $2 \sigma^{7} \sigma^{7}$; Aug. 17, $9 \sigma^{7} \sigma^{7}, 1$ \% ; Aug. 18,

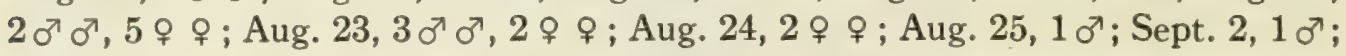
Sept. 15, 2 \% 9 ; Sept. 23, $4 \sigma^{7} \sigma^{7}$; Sept. $25,2 \sigma^{7} \sigma^{7}$; 1938. Leamington: Sept. 15, 1938, $3 \sigma^{7} \sigma^{7}$. Windsor: Sept. 25, 1938, $2 \sigma^{7} \sigma^{7}$. Tecumsen: Aug. 27, 1938, $1 \sigma^{7}$. EsseX: Aug. 31, 1938, 2 ㅇ. Staples: Aug. 27, 1938, $60^{7} \sigma^{7}, 1 \%$. Arner: Sept. 5, 1938, 2 o $^{7} \sigma^{7}, 3$ ㅇ 우 ; Aug. 12, 1938, $10^{7}, 1$; Aug. 19, 3 o $^{7} \sigma^{7}, 3$ 우 92 nymphs; 1938. Wheatley: Sept. 25, 1938, $1 \sigma^{7}$. Oxley: Sept. 26, 1938, 1 \% . South Woodslee: Sept. 27, 1938, 2 ㅇ․ Maidstone: Sept. 27, 1938, $1 \sigma^{7}$. Cottam: Sept. 27, 1938, $10^{7}$. Amherstburg: Aug. 25, 1938, $20^{7} 0^{7}, 5$ 우.

\section{O. gladiator (Bruner)}

This species inhabits marsh areas throughout Essex County.

Walker (1905) has previously recorded this species from Point Pelee.

Point Pelee: July 4, 2 nymphs; July $8,1 \sigma^{7}$; July $11,13 \sigma^{7} \sigma^{\top}, 5$ ㅇ ㅇ , 4 nymphs;

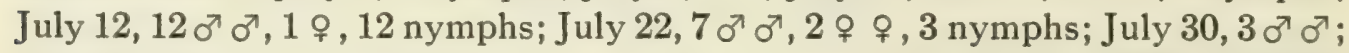
July 23, $3 \sigma^{7} \sigma^{7}, 1$; ; July $28,1 \sigma^{7}, 1$ \% ; Sept. $2,1 \sigma^{7}$; Sept. 8, $1 \sigma^{7}$; 1938. ARNER: Aug. 12, 1938, $5 \sigma^{\top} \sigma^{\top}, 1$ nymph. MACGregor: Sept. 26, 1938, $1 \sigma^{\top}$.

\section{O. volantum McNeill}

One observation on the habits of this species may be worth recording: On August 27, while collecting at Tecumseh, a number 
of males could be heard stridulating among the sedges growing in water that was approximately eighteen inches deep. By following the sound to its source, the specimen could be found clinging to the upright sedge and, in true Orchelimum fashion, would dodge to the far side of the sedge to escape detection. But, on attempting to capture the specimen, it would immediately leap into the water and swim vigorously to another clump of sedges, there to cling to an upright stem or leaf and remain motionless, sometimes beneath the surface of the water.

Since $O$. volantum is nearly always found upon vegetation growing in open water ponds, it is interesting to correlate the above apparent semi-aquatic habit of the species with its ecological distribution. It may also be inferred that the eggs can withstand submergence; even though the eggs may be deposited in the aerial portion of aquatic vegetation, the latter, due to the snow and ice of winter, is completely submerged in early spring.

This is not as common as are the other species of Orchelimum and appears to be limited to marsh areas that have a considerable amount of surface water, such as those located along the margins of lakes and ponds. Except for the specimens taken at Point Pelee all those that are here recorded were from marshes situated along the shores of Lake Erie and Lake St. Clair.

Walker (1905) has previously recorded this species from Point Pelee.

Point Pelee: Aug. 8, 1901, $3 \sigma^{7} \sigma^{7}, 7$ ㅇ ㅇ, Walker; Aug. 6, $6 \sigma^{7} \sigma^{7}$; Sept. $2,3 \sigma^{7} \sigma^{7}$; Sept. 24, $1 \sigma^{7}$; 1938. Tecumsen: Aug. 27, 1938, $2 \sigma^{\top} \sigma^{\nearrow}$. Belle River: Aug. 27, 1938, $1 \sigma^{7}$. Malden Centre: Aug. 19, 1938, $8 \sigma^{\top} \sigma^{\top}, 5$ 우.

\section{O. concinnum concinnum Scudder}

Owing to the amount of variation in the size of the body, the shape and size of the ovipositor and the occasional presence of a median facial stripe, a certain amount of confusion has arisen in the identification of this species in the past. Walker (1905) listed campestre, indianense, and delicatum as distinct species, all of which have been referred to concinnum. Rehn and Hebard (1915) placed Blatchley's campestre as a synonym of concinnum. The $O$. delicatum listed by Walker was apparently sent to Blatchley "who gave his opinion that it was probably delicatum".

Although most of the specimens taken had the face immaculate, a number had a distinct, median, dark brown stripe, while others exhibited a certain amount of gradation between these two extremes (see fig. 3). This collection also illustrated a tendency towards the striped condition in certain localities and the reverse condition in others as shown in the accompanying table: 
Locality

(1) Point Pelee.

Malden Centre .

(2) Point Pelee.

$\begin{array}{cc}\begin{array}{c}\text { No. of } \\ \text { specimens }\end{array} & \begin{array}{c}\text { Face } \\ \text { striped }\end{array} \\ 17 & 14 \\ 16 & 4 \\ 41 & 1\end{array}$

$\begin{array}{cc}\begin{array}{c}\text { Face } \\ \text { immaculate }\end{array} & \begin{array}{c}\text { Percentage with } \\ \text { face striped }\end{array} \\ 3 & 82 \\ 12 & 25 \\ 40 & 2.5\end{array}$

In a number of marshes not a single striped specimen was taken.

Hebard (1934) states that concinnum delicatum is a western race, the males of which cannot be separated from those of concinnum

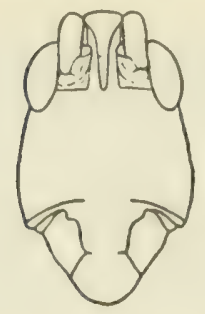

a

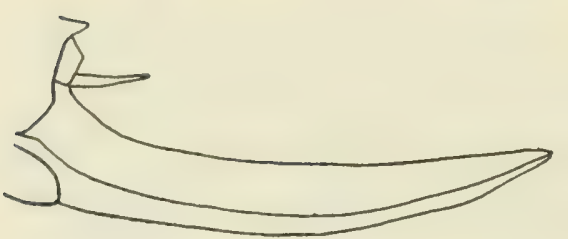

e

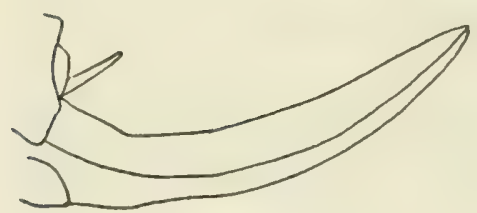

8

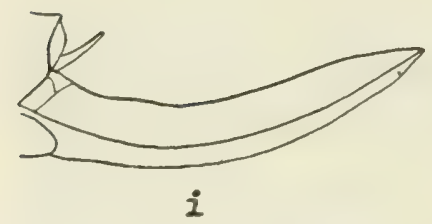

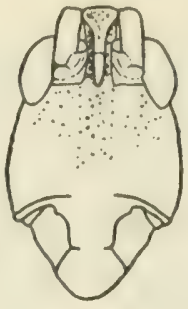

b

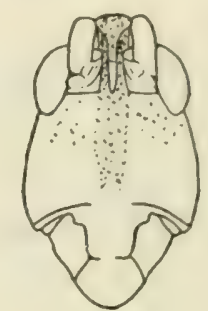

C

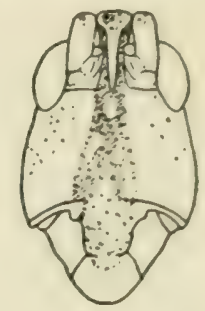

d
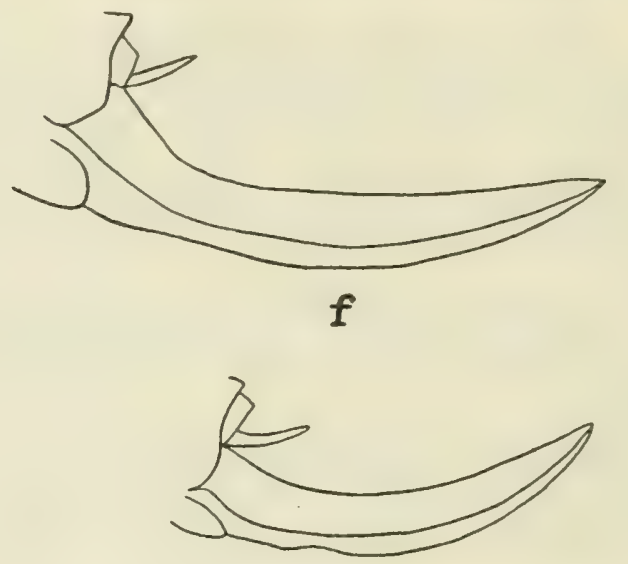

h

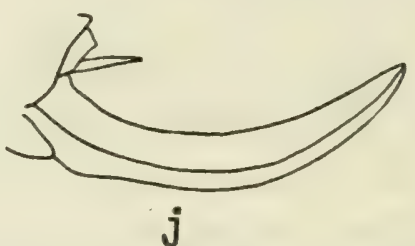

FIGURE 3.-a-d, facial view of $O$. concinnum showing the variation in the amount of pigmentation; $e-j$, variations in the size and amount of curvature of the ovipositor of $O$. concinmim (drawn to scale).

concinnum; the females are apparently distinguishable on the basis of the form and length of the ovipositor. According to Hebard, there is apparently no area of intergradation of the kind usually found between geographic races. From Indiana to eastern Nebraska and Kansas typical concinnum is strongly dominant but occasionally females representing concinnum delicatum are found. 
In so far as the material considered in this paper is concerned, the shape of the ovipositor varies considerably (see fig. 3 ); in some specimens the dorsal margin is quite straight while in others it is gently upcurved; the size is also variable, being comparatively broad in some specimens and narrow in others. Hence, in so far as the amount of curvature and size of the ovipositor are concerned, individuals in the material from Essex County may apply to both forms.

O. concinnum inhabits open marsh areas, especially among the tall grasses and sedges growing along the shores of Lake Erie and Lake St. Clair.

O. concinnum concinnum has been recorded as campestre, indianense and delicatum from Point Pelle and Arner by Walker (1905). Point Pelee: Aug. 8, 1901, $3 \sigma^{7} \sigma^{7}$, Walker; July 12, $1 \sigma^{7}$; July 22, $2 \sigma^{7} o^{7}, 6$ \% 9 ;

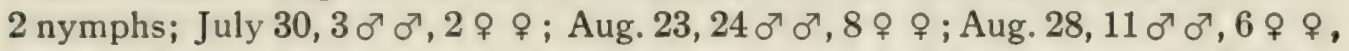
Aug. 30, $2 \sigma^{7} \sigma^{7}$; Sept. $2,13 \sigma^{7} \sigma^{7}, 6$ ㅇ ㅇ, 2 nymphs; Sept. 8, $20^{7} \sigma^{7}$; Sept. $15,11 \sigma^{7} \sigma^{7}$, 2 ㅇ, 1 nymph; Sept. 16, 1 ; 1938 . Stony PoInt: Aug. 27, 1938, $1 \sigma^{7}$. Arner: Aug. 12, $1 \sigma^{7}$; Aug. 19, $3 \sigma^{7} \sigma^{7}, 1$ \% ; 1938. Malden Centre: Aug. 19, 1938, $14 \sigma^{7} \sigma^{7}, 2$ \% . Amherstburg: Aug. 25, 1938, $12 \sigma^{7} \sigma^{7}, 1$ ㅇ, 1 nymph. Kingsville: Aug. 9, 1901, $1 \sigma^{\text {T}}$; Walker.

\section{Conocephalus Thunberg}

\section{C. nigropleurum (Bruner)}

This species is not very abundant and is, apparently, confined to the more southern portions of Essex County where it inhabits small marshes and the margins of streams and creeks.

Walker (1904) has recorded this species from Arner.

Point Pelee: July 4, 1 nymph; Sept. $2,1 \sigma^{7}, 1$; Sept. 16,1 ; 1938. Arner: Aug. 19, $1 \sigma^{7}$; Sept. 5, $2 \sigma^{7} \sigma^{7}$; 1938. Kingsville: Aug. 9, 1938, $1 \sigma^{7}$.

\section{C. attenuatus (Scudder)}

There is considerable variation in the length of the ovipositor; from an examination of 45 specimens chosen at random from a collection of 130 , the following measurements expressed in millimetres were obtained; the number of specimens in parenthesis: 29.0 (1); 27.0 (1); 26.2 (4); 26.0 (4); 25.5 (1); 25.0 (9); 24.0 (6) $23.0(3) ; 21.0(4) ; 20.0(6) ; 19.0(3) ; 18.8$ (1); 18.0 (1).

Although the majority of the specimens from this locality are uniformly light straw-brown in colour, many of them have bright green legs (160 with legs brown; 108 with legs bright green).

All of the specimens taken in the summer of 1938 (241 specimens) are short-winged. Only one long-winged specimen was taken in this locality by Walker on Aug. 8, 1901. Long-winged forms have been taken in other localities in Southern Ontario (Toronto, Walpole 
Island, and Brockville); they were of common occurrence (38\% of the collection) in a small marsh at Brockville in eastern Ontario.

This graceful long-horned grasshopper is found throughout Essex County and was the most abundant species present in the marsh at Malden Centre.

This species has been previously recorded from Point Pelee by Walker (1904).

Point Pelee: Aug. 16, $1 \sigma^{x}$; Aug. 28, $21 \sigma^{7} \sigma^{7}, 12$ \% ㅇ ; Aug. 30, $5 \sigma^{x} \sigma^{x}, 1$ 우 ; Sept. 8, $34 \sigma^{7} \sigma^{7}, 23 \%$ \% : Sept. 15, $7 \sigma^{7} \sigma^{7}, 3$ \% $\%$; 1938. ARner: Aug. 12, 2 ㅇ ; Aug. 19, $2 \sigma^{7} \sigma^{7} ;$ 1938. Malden Centre: Aug. 19, 1938, $90 \sigma^{7} \sigma^{7}, 29 \%$ $\%, 9$ nymphs.

Amherstburg: Aug. 25, 1938, 10 .

\section{C. strictus (Scudder)}

Although this species may be found throughout Essex County it is not very abundant in any locality. It inhabits meadows of long grass and the grassy margins of roadways and the like.

Of the total collection of 57 specimens, only one macropterous individual was taken at Wheatley on September 25.

This species has been recorded from Essex County by Walker and Urquhart (1940).

Point Pelee: July 24, 1 nymph; Aug. 3, $1 \sigma^{x}$; Aug. 6, 1 nymph; Aug. 12, $10 \sigma^{7} \sigma^{x}$, 2 우 우; Aug. 17, $2 \sigma^{7} \sigma^{\top}$; Aug. 18, $1 \sigma^{x}$; Aug. 28, 1 우; Aug. 15, $5 \sigma^{7} \sigma^{x}$; Sept. 15, $1 \sigma^{7}$, 1 ㅇ ; 1938. Leamington: Sept. 15, 1938, $5 \sigma^{\top} \sigma^{7}, 2$ 우. 으. La Salle: Aug. 25, 1938, $7 \sigma^{\top} \sigma^{7}, 4$ ㅇ ㅇ, 1 nymph. Kingsville: Aug. 25, 1938, $1 \sigma^{7}, 2$ nymphs. Windsor: Aug. 27, 1938, 1 万ٓ Tecumsen: Aug. 27, 1938, 1 ㅇ. Belle River: Aug. 27, 1938, 1 우. Essex: Aug. 31, 1938, $2 \sigma^{7} \sigma^{7}, 1$ ㅇ․ Staples: Aug. 27, 1938, $1 \sigma^{7}, 1$ ㅇ․ Windfall: Sept. 25, 1938, $3 \sigma^{7} \sigma^{7}, 2$ 우 ㅇ․ Amherstburg: Aug. 25, 1938, 1 ठ․

\section{C. brevipennis (Scudder)}

This species is almost as common as fasciatus although not quite so ubiquitous, being usually confined to marsh areas or humid meadows.

Previously recorded from Arner by Walker (1904).

A series of 379 specimens was obtained from all of the localities in Essex County considered in this paper.

\section{C. fasciatus fasciatus (DeGeer)}

Extremely abundant throughout Essex County, especially in low-lying, grassy fields.

Previously recorded from Point Pelee, Leamington and Arner by Walker (1904).

A series of 585 specimens was obtained from Essex County, representing all of the localities considered in this paper. 


\section{COPIPHORINAE}

\section{Neoconocephalus Karney}

\section{$N$. ensiger (Harris)}

Common throughout Essex County, inhabiting pasture fields and other areas of long grass.

Previously reported from Leamington by Walker (1904).

Point Pelee: July 4, 1 nymph; July 11,1 nymph; July 12,1 nymph; July 24 , $8 \sigma^{x} \sigma^{7}, 1$ \% ; July 27, $5 \sigma^{x} \sigma^{x}$; July 29, $14 \sigma^{7 x} \sigma^{x}$; Aug. $1,9 \sigma^{7} \sigma^{7}$; Aug. 3, $1 \sigma^{x}$; Aug. 6, $2 \sigma^{7} \sigma^{7}$; Aug. 7, $1 \sigma^{7}$; Aug. 9, $1 \sigma^{7}$; Aug. 18, $1 \sigma^{x}$; Aug. 30, $1 \sigma^{x}$; Sept. 15, $1 \sigma^{x}$; 1938. Arner: Aug. 19, 1938, 1 \%.

N. lyristes (Rehn and Hebard)

This species was recorded from Sarnia, at the source of the St. Clair River, by Walker (1904) as Conocephalus nebrascensis and later as Neoconocephalus lyristes by Walker and Urquhart (1940). It may occur in parts of Essex County.

\section{Phaneropterinae \\ Amblycorypha Stål}

\section{A. oblongifolia (DeGeer)}

Common throughout Essex County, inhabiting grassy fields, especially those around the margin of an open woodlot.

Of the series of 40 specimens, six are uniformly brown in colour. One pink specimen was taken at Windsor on September 13, 1940, by Mrs. G. Mullin.

Walker (1904) has recorded this species from Point Pelee and Arner.

Point Pelee: Aug. 7, 1901, $1 \sigma^{x}$, Walker; July 24, 1 nymph; July 29, $2 \sigma^{7} \sigma^{x}$; Aug. 6, $13 \sigma^{7} \sigma^{7}$; Aug. 7, $1 \sigma^{7}$; Aug. 17, $10 \sigma^{7} \sigma^{7}$; Aug. 18, $1 \sigma^{7}, 1$ 우 ; Aug. 24, $1 \sigma^{7}$; Sept. 8, $1 \sigma^{7}, 1$ \% ; Sept. 14, $4 \sigma^{7} \sigma^{7}, 1$ \% ; 1938. Kingsville: Aug. 9, 1901, $1 \sigma^{7}$, Walker. Harrow: Sept. 26, 1938, 1 \%. Windsor, Sept. 13, 1940, $1 \sigma^{\top}$, Mullin.

\section{Scudderia Stål}

\section{S. curvicauda curvicauda DeGeer}

Walker (1904) reported two specimens taken at Arner on August 9, 1901. It is apparently of rare occurrence in Essex County, not a single specimen having been taken by the writer throughout the entire summer of 1938.

\section{S. furcata furcata Brunner}

Although occurring throughout Essex County it is not of common occurrence and appears to be limited to the margins of wooded areas. 
Previously reported from Point Pelee and Arner by Walker (1904); and from Kingsville by Urquhart (1940).

Point Pelee: Aug. 9, 1901, $1 \sigma^{7}$, Walker; Aug. 23, 1920, $2 \sigma^{7} \sigma^{7}$, Bigelow; July 24, 2 nymphs; July 29, $1 \sigma^{7}$; Aug. 1, $1 \sigma^{7}$; Aug. 8, $1 \sigma^{7}, 1$ nymph; Aug. 10, $1 \sigma^{7}$; Aug. 17. $4 \sigma^{7} \sigma^{7}$; Aug. 18, $3 \sigma^{7} \sigma^{7}$; Aug. 23, $2 \sigma^{7} \sigma^{7}, 1$ \% ; Aug. 24, $2 \sigma^{7} \sigma^{7}$; Aug. 25, 2 \% ; 1 1938, Kingsville: Aug. 9, 1901, $1 \sigma^{7}$, Walker. Leamington: Sept. 15, 1938, $1 \sigma^{7}$.

S. texensis Saussure and Pictet

Common throughout Essex County in low-lying, humid meadows or marshes.

Previously recorded from Point Pelee and Arner by Walker (1904); and from Kingsville, Essex, Tecumseh, Amherstburg, La Salle, Malden Centre, Colchester, and Oxley by Urquhart (1940). Point Pelee: Aug. 8, 1901, 1 ð7. Walker; July 4, 5 nymphs; July 12, 7 nymphs; July 27, $1 \sigma^{7}$; Aug. 6, $1 \sigma^{7}$; Aug. 23, $2 \sigma^{7} \sigma^{7}, 2$ nymphs; Sept. 2, $7 \sigma^{7} \sigma^{7}, 3$ 우 우; Sept. 16, $1 \sigma^{7}, 11 \%$ 우 1938. La Salle: Aug. 25, 1938, 1 \%. Kingsville: Aug. 9, 1901, $2 \sigma^{\top} \sigma^{\top}$, Walker. Aug. 25, 1938, 1 \%. Tecumsen: Aug. 27, 1938, $1 \sigma^{x}, 1 \%$. Essex: Aug. 31, 1938, $1 \sigma^{7}$. Arner: Aug. 19, 1938, $1 \sigma^{7}, 1 \%$. MACGregor: Sept. 26, 1938, $2 \sigma^{7} \sigma^{7}, 1 \%$. Oxley: Sept. 26, 1938, 2 \% . Colchester: Sept. 26, 1938, 1 ㅇ. Malden Centre: Aug. 19, 1938, 2 웅․ AmHerstburg: Aug. 25, 1938, $5 \sigma^{7} \sigma^{7}, 3$ ㅇ .

\section{CAELIFERA}

\section{TRIDACTYLOIDEA \\ TRIDACTYLIDAE}

The family Tridactylidae has been considered, by a number of American students of Orthoptera, as a subfamily (Tridactylinae) of the Gryllidae related to the mole-crickets, Gryllotalpinae. The work of Carpentier (1936), Ander (1939) and others, however, has produced sufficient evidence to substantiate the conclusion that the tridactylids are not closely related to the crickets but have stronger affinities with the Acridoidea. In the present paper the classification proposed by Ander (1939) has been adopted since it presents more accurately the relationship of the so-called "pygmy molecrickets".

\section{T. apicalis Say}

\section{Tridactylus Olivier}

Found along the sandy banks of creeks and ponds or in damp, sandy fields under cultivation.

Pornt Pelee: Sept. 7, 1938, 15 adults, 17 nymphs.

T. minutus Scudder

Although specimens of this species have not been taken in Essex County it doubtless occurs since specimens have been taken at 
Morpeth (Walker and Urquhart, 1940) and Port Rowan in southwestern Ontario (Urquhart, 1941).

\section{ACRIDOIDEA \\ ACRYDIIDAE}

\section{Acrydium Geoffroy}

\section{A. arenosum obscurum (Hancock)}

This small locust was found inhabiting moist situations in the open clearing of the hardwood forest of Point Pelee.

Point Pelee: June 19, $1 \sigma^{7}, 1$ \% ; June 28,1 \% ; 1938.

\section{A. subulatum Linnaeus (Syn.-A. granulatum)}

This species is, no doubt, common throughout Essex County, inhabiting humid situations such as the margins of marsh areas, the borders of small creeks and densely wooded areas. The specimens here recorded were taken at the margin of the marsh and in an open clearing in a hardwood forest at Point Pelee.

Point Pelee: Aug. 28, 7 nymphs; Sept. 9, $2 \sigma^{7} \sigma^{7}, 3$ \% ㅇ ; Sept. 15, $18 \sigma^{7} \sigma^{7}, 12$ \% ㅇ 1938.

\section{A. ornatum Say}

Inhabits open grassy areas such as pasture fields, and the grassy margins of wooded sections.

Point Pelee: June 16, 1 \% ; Aug. 3, 1 \% ; Aug. 17, 1 ơ $^{7}$; Sept. 15, 1 o $^{7}$; 1938.

\section{Paratettix Bolivar}

\section{P. cucullatus (Burmeister)}

Common along the margins of marshes.

Point Pelee: June 14, 1920, $1 \sigma^{7}$, Bigelow; June 20, $1 \sigma^{7}, 10 \%$ \&, 1 nymph; July 4,5 ơ $^{7}, 5$ \& $\& ; 1938$.

\section{Tettigidea Scudder}

\section{T. lateralis parvipennis (Harris)}

Of common occurrence in pasture fields.

Previously recorded from Arner by Walker (1902a).

Kingsville: Aug. 9, 1901, 3 nymphs, Walker; June 14, 1920, $10^{7}, 1$ ㅇ , Bigelow. Point Pelee: Aug. 23, 2 \% $\%, 1$ nymph; Sept. 8, $1 \sigma^{7}, 1$ \% 3 nymphs; 1938. Wheatley: Sept. 25, 1938, 2 \% , 1 nymph. 


\section{ACRIDIDAE}

ACridinae

Pseudopomala Morse

\section{$P$. brachyptera (Scudder)}

This species is undoubtedly of rare occurrence in Essex County, and limited to marsh areas in proximity to the shore of Lake Erie.

Previously recorded from this locality by Walker and Urquhart (1940).

ArNer: Aug. 19, 1938, 1 ㅇ.

\section{Metaleptea Fabricius}

\section{M. brevicornis (Linnaeus)}

This apparently rare species has been taken in only two localities in the southern part of the county.

Point Pelee: Aug. 8, 1901, $2 \sigma^{7} \sigma^{7}$, Walker (1902a). Arner: Aug. 12, 1938, 3 o $^{7}, 1$ \%, 1 nymph.

\section{Orphulella Giglio-Tos}

O. pelidna (Burmeister)

Although O. pelidna has not been taken in Essex County it probably occurs in this locality since specimens have been taken by Walker (1902) at Sarnia and by the writer at Port Rowan; in the latter locality it was found to be quite abundant on low-lying, humid, sandy soil.

O. speciosa (Scudder)

Inhabiting rather dry pastures throughout Essex County.

Previously recorded from Arner by Walker (1902a).

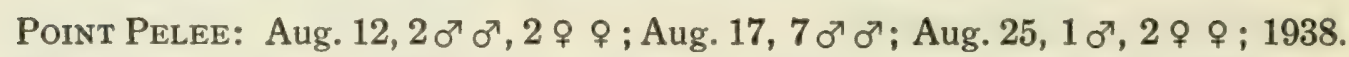
Windsor: Aug. 25, 1938, $4 \sigma^{7} \sigma^{7}, 5$ ㅇ ㅇ. Belle River: Aug. 27, 1938, $1 \sigma^{7}$, 2 우. Essex: Aug. 31, 1938, $4 \sigma^{\top} \sigma^{\top}, 5$ 우. Wheatley: Sept. 25, 1938, 1 ․

\section{C. conspersa Harris}

\section{Chloealtis Harris}

In grassy fields at the margins of woodlots throughout Essex County.

Previously recorded from Kingsville, Point Pelee and Arner by Walker (1898).

Point Pelee: June 8, 2 nymphs; June 12, 1 nymph; June 19, 2 nymphs; July 8 , $8 \sigma^{7} \sigma^{x}$; July 19, $1 \sigma^{x}, 1$ 우 ; July 22, 1 ㅇ ; July 29, $1 \sigma^{x}$; Aug. 13, $1 \sigma^{7}$; 1938 ; Aug. 7, 1901, 1 \%, Walker; Aug. 11, 1920, 2 \% , Bigelow. Kingsville: Aug. 12, 1 , Walker. 


\section{Chorthippus Fieber}

C. longicornis Latreille (Syn.-C. curtipennis (Harris)

Inhabits humid pastures and the grassy margins of marshes.

Previously recorded from Point Pelee and Arner by Walker (1902a).

The series of specimens before me represent all of the localities of Essex County considered in this paper.

\section{S. lineatum (Scudder)}

Stethophyma Fischer

Of common occurrence in small inland marshes.

Previously recorded from Point Pelee by Walker (1902a).

Point PeleE: Aug. 8, 1901, $10^{7}, 3$ $~ ९$, Walker; July 30, 1 nymph; Aug. 28, $1 \sigma^{\gamma}, 2$ \% ; Sept. $2,1 \sigma^{\gamma} ; 1938$. ARnER: July 19, 1 \% Sept. $5,1 \sigma^{7}, 1 \% ; 1938$.

\section{A. sulphurea Stal}

\section{OEDIPODINAE}

Walker (1898) reported this species as common in the vicinity of Toronto. Specimens in the collection of the Royal Ontario Museum of Zoology have been taken at Port Dover, Rondeau, Grand Bend, London, and Bothwell. It was also taken by the writer at Port Rowan and Turkey Point where it was found to be quite abundant. From such records as these we would expect to find this species in parts of Essex County although, as yet, no records of its occurrence have been made in this locality.

$A$. sulphurea occurs in the adult condition in the spring and early summer and inhabits dry sandy fields and hillsides.

\section{Chortophaga Saussure}

\section{C. viridifasciata (DeGeer)}

Common throughout Essex County, inhabiting pastures. Adults occur in early summer.

Previously recorded from Arner by Walker (1902a). Point Pelee: June 16, $10^{\text {T}}$; Aug. 23, 3 nymphs; Sept. 8, 3 nymphs; 1938. EsseX: Aug. 31, 1938, 2 nymphs. Wheatley: Sept. 25, 1938, 5 nymphs. Amherstburg: Aug. 25, 1938, 1 nymph.

\section{Encoptolophus Scudder}

E. sordidus sordidus (Burmeister)

Inhabiting pastures and shrub areas along the margins of beaches. 
Previously recorded from Arner by Walker (1902a).

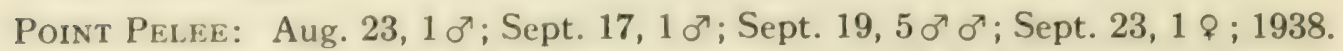
Windsor: Aug. 25, 1938, 1 ㅇ. Essex: Aug. 31, 1938, $1 \sigma^{7}$. Arner: Sept. 5, 1938, 1 \% . Wheatley: Sept. 25, 1938, 1 ㅇ. South Woodslee: Sept. 27, 1938, $1 \sigma^{7}$. Cotтaм: Sept. 27, 1938, 1 \% .

\section{Camnula Stål}

\section{C. pellucida Scudder}

Apparently of rare occurrence in Essex County. Not a single specimen was taken by the author throughout the entire summer of 1938. It has, however, been recorded by Walker (1902a) from Point Pelee.

\section{Pardalophora Saussure}

P. apiculata (Harris)

Since specimens of $P$. apiculata have been taken at Rondeau it may occur in parts of Essex County, although there are no records from the latter locality.

\section{Dissosteira Scudder}

D. carolina (Linnaeus)

This is one of the most abundant species of oedipodine found in rather dry pastures and dusty roadways throughout Essex County.

Previously recorded from Point Pelee and Arner by Walker (1902a).

Point Pelee: June 12, 1 nymph; July 10, $2 \sigma^{7} \sigma^{7}, 2$ \% ; July $24,4 \sigma^{7} \sigma^{7}, 1$ ㅇ, 3 nymphs; Aug. 9, $20^{7} 0^{7}, 2$ ㅇ 우; Sept. 1, 1 ․ Essex: Aug. 31, 1938, $1 \sigma^{7}$.

S. bolli Scudder

\section{Spharagemon Scudder}

Inhabits rather dry grasslands.

Previously recorded from Point Pelee and Arner by Walker (1902a).

Point Pelee: Aug. 9, 1901, $2 \sigma^{7} \sigma^{7}, 2$ \% ㅇ, Walker; June 12, 2 nymphs; July 24, $2 \sigma^{7} \sigma^{7}$; Aug. 17, $1 \sigma^{7}$; Aug. 23, $3 \sigma^{7} \sigma^{7}, 1$ \% ; Aug. 25, $1 \sigma^{7}$; Sept. 7, $1 \sigma^{7}$; Sept. 8, $1 \sigma^{7}$; 1938. ARnER: Aug. 9, 1901, $40^{7} \sigma^{7}, 1$ \% , Walker.

S. collare wyomingianum (Thomas)

Wyomingianum was first described by Thomas (1872) and later placed in synonomy with collare by Kirby (1910). Blatchley (1920) considered wyomingianum as a distinct species to which conclusion Hebard (1925) was in disagreement. The latter author (1934) later recorded this species (wyomingianum) as S. collare. Blatchley (1920) 
concluded that the retaining of wyomingianum as distinct was more or less arbitrary and a matter of individual opinion.

That Ontario specimens are separable into collare and wyomingianum has been previously mentioned by Walker and Urquhart (1940); attention was drawn to the fact that specimens from Southampton were decidedly larger than those taken in other parts of Ontario which material we concluded was $S$. collare collare; this is quite obvious from the table of measurements and the accompanying figures of the tegmina (Fig. 4).
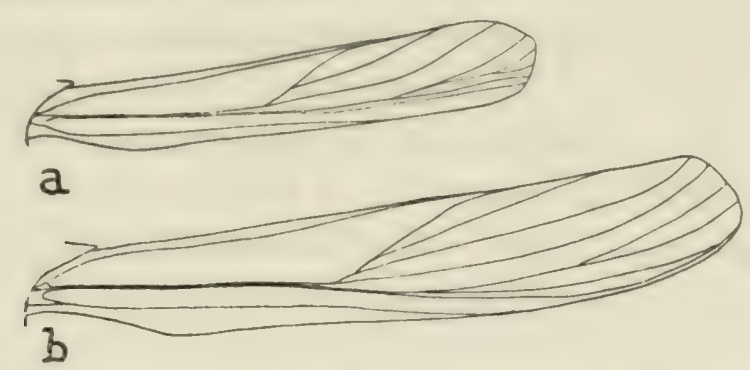

FIgURE 4.-a, left tegmen of S. c. wyomingiamum from Southampton; b, same of $S$. c. collare from Point Pelee (drawn to scale).

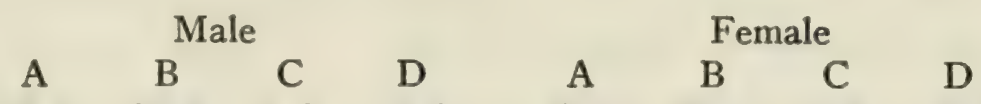

(1) Southampton . $\begin{array}{rrrrrrrr}33.0 & 26.5 & 5.0 & 14.0 & 37.0 & 30.4 & 5.3 & 16.0\end{array}$ $\begin{array}{llll}37.0 & 29.0 & 5.3 & 15.5\end{array}$ $\begin{array}{llll}37.3 & 29.0 & 5.3 & 15.8\end{array}$ $\begin{array}{llll}38.0 & 29.4 & 5.0 & 15.5\end{array}$

Av..... $\begin{array}{llll}37.3 & 29.5 & 5.2 & 15.7\end{array}$

$\begin{array}{llllllll}\text { (2) Point Edward. } 23.5 & 18.0 & 3.2 & 12.0 & 32.0 & 25.0 & 4.5 & 14.0\end{array}$

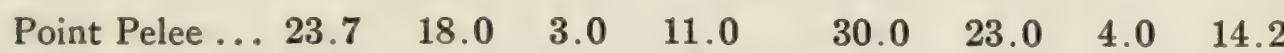
$\begin{array}{llllllll}24.5 & 19.3 & 3.1 & 10.8 & 30.5 & 24.0 & 4.0 & 14.2\end{array}$ $\begin{array}{llllllll}27.0 & 21.0 & 3.3 & 13.0 & 32.0 & 25.0 & 4.0 & 14.0\end{array}$ $\begin{array}{llllllll}27.2 & 21.0 & 3.8 & 12.2 & 30.2 & 24.0 & 4.0 & 14.0\end{array}$

\begin{tabular}{rrrrrrrrr} 
Av..... & 25.6 & 19.8 & 3.3 & 11.8 & 30.7 & 24.0 & 4.0 & 14.0 \\
Rondeau...... & 21.5 & 17.5 & 2.8 & 9.8 & 30.0 & 23.2 & 4.0 & 14.0 \\
24.0 & 18.3 & 3.2 & 10.4 & 29.0 & 22.2 & 3.6 & 14.2 \\
23.5 & 18.0 & 3.0 & 11.0 & 26.5 & 21.0 & 4.0 & 13.0 \\
23.0 & 17.8 & 3.0 & 10.3 & 30.0 & 22.5 & 4.0 & 13.0 \\
\cline { 2 - 8 } & & & & & & & \\
Av . . 23.0 & 17.9 & 3.0 & 10.4 & 28.9 & 22.2 & 3.9 & 13.6
\end{tabular}

A-length to tip of tegmina; B-length of tegmina; C-width of tegmina; $\mathrm{D}$-length of hind femur.

(1) -only one male specimen taken in this locality.

(2) -only two specimens, $\sigma^{7}$ and $\&$, taken in this locality.

Width of the tegmina taken one-third from its apex. 
In addition to the difference in size, two of the five specimens from Southampton are distinctly "collared", thus more closely resembling specimens collected in the western provinces.

Owing to a lack of sufficient material from other localities, it is not possible, at present, to formulate any definite conclusions as to the origin of these two distinct races in Ontario. However, it might be suggested that the specimens found in south-western Ontario arrived by two different routes with the retreat of the last ice sheet. $S$. collare collare, found in the northern sections of south-western Ontario, may have advanced northward along a route west of the Great Lakes and entered Ontario from the north-west, while S. collare wyomingianum, found along the shores of Lake Ontario and Lake Erie, may have advanced in a north-easterly route entering Ontario from the south-west. It is conceivable that the two forms merge imperceptibly to the south.

Spharagemon collare wyomingianum was taken in the more southern parts of Essex County where it was found inhabiting rather dry, grassy pastures on Point Pelee; it has been previously recorded from this locality by Walker (1902a).

Point Pelee: Aug. 7, 1901, $6 \sigma^{7} \sigma^{7}, 3$ \% $९$, Walker; June 12, 2 nymphs; July 24,

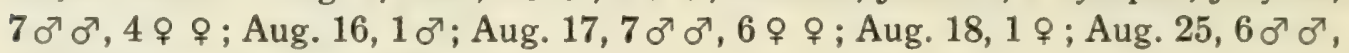
4 우 우; Sept. 19,1 우; 1938.

\section{Trimerotropis Stål}

\section{T. maritima interior E. M. Walker}

On the sand dunes and beaches along the north shore of Lake Erie, and sandy, cultivated fields in the interior of Point Pelee.

Previously recorded from Point Pelee and Kingsville by Walker (1898).

Point Pelee: Aug. 7, 1901, $3 \sigma^{7} \sigma^{7}, 4$ 우 우 Walker; June 21, $1 \sigma^{7}, 7$ nymphs;

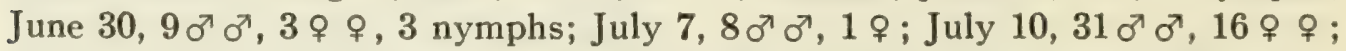
July 22, $8 \sigma^{7} \sigma^{x}, 7$ ㅇ 우; Aug. 8, 1 웅 Aug. 24, $41 \sigma^{7} \sigma^{7}, 10$ 우 우; Sept. 23, $2 \sigma^{7} \sigma^{7}$, 2 nymphs; Sept. 25, $2 \sigma^{7} \sigma^{7}, 3$ 우 우, 2 nymphs; 1938 . Kingsville: Aug. 13, 1901, $2 \sigma^{7} \sigma^{x}$, Walker. Tecumsen: Aug. 27, 1938, $2 \sigma^{x} \sigma^{x}, 1$ nymph.

\section{Cyrtacanthacrinae}

\section{Schistocerca Stål}

\section{S. americana americana (Drury)}

This species occurs in the southern parts of Essex County during early summer, especially in sandy, cultivated fields at the southern tip of Point Pelee. Adults also occur in late summer although apparently not as abundant at this time (Urquhart, 1938). 
Point Pelee: June 29, 1 \& ; July 7, 1 \% ; July 19, $1 \sigma^{7}$; Aug. 6, 1 nymph; Sept. 15, 1 nymph; 1938. Ruthven: Sept. 27, 1938, 1 ․

\section{Melanoplus Stål}

\section{M. viridipes Scudder}

It has been previously pointed out (Walker and Urquhart, 1940) that the cerci of the specimens recorded in this present paper are intermediate between those of $M$. v. viridipes and $M$. v. eurycercus Hebard.

This small short-winged locust is not common in Essex County; it is here recorded from only one locality.

Leamington: June $28,1922,4 \sigma^{7} \sigma^{7}, 3$ ㅇ 우, Walker.

M. fasciatus (F. Walker)

This species, although common in the more central and northern portions of Southern Ontario, is apparently of rare occurrence in Essex County. It is confined to rather dry pastures in proximity to open woodlots.

Previously recorded from Point Pelee by Walker (1902a).

Point Pelee: Aug. 7, 1901, Walker.

\section{M. mexicanus mexicanus (Saussure)}

Inhabits pastures and grassy areas on the sand dunes of Point Pelee.

Point Pelee: A series of 72 specimens taken throughout the summer from June 8 to September 25, 1938. Leamington: Sept. 15, 1938, 1 \%. La Salle: Aug. 25, 1938, 1 \%. Staples: Aug. 27, 1938, $4 \sigma^{7} \sigma^{7}, 1$ \%. It occurred in all of the localities of Essex County considered in this paper.

\section{M. femur-rubrum femur-rubrum (DeGeer)}

Found in abundance in nearly every pasture and especially at the margins of marshes and meadows.

Previously recorded from Arner and Point Pelee by Walker (1902a).

A series of 444 specimens representing all of the localities of Essex County considered in this paper.

\section{M. keeleri luridus (Dodge)}

Inhabits open dry pastures at the margins of woodlots in Point Pelee.

Previously recorded from Arner and Point Pelee by Walker (1902a).

Point Pelee: Aug. 7, 1901, $1 \sigma^{7}$, Walker; Aug. 23, $6 \sigma^{7} \sigma^{\nearrow}, 3$ ㅇ ๆ ; Sept. 19, $3 \sigma^{\sigma^{7}} \sigma^{7}$, 4 우 우 1938. 


\section{M. bivittatus (Say)}

In tall grasses growing at the margins of marshes and meadows.

Previously recorded from Point Pelee and Arner by Walker (1902a).

Point Pelee: A series of 47 specimens taken from June 20 to August 28. WindSOR: Aug. 27, 1938, 1 . Essex: Aug. 31, 1938, $5 \sigma^{7} \sigma^{7}, 6$ \% $\%$. Arner: Aug. 12, 1938, $1 \sigma^{7}, 1$ ㅇ. Windfall: Sept. 25, 1938, $1 \sigma^{7}, 6$ 우. Ruthven: Sept. $27,1938,1$ ㅇ․

\section{M. differentialis (Thomas)}

Of rare occurrence and apparently confined to marshy areas close to the north shore of Lake Erie (Walker and Urquhart, 1940). Point Pelee: Sept. 1, 1938, 1 \% . Colchester: Sept. 26, 1938, $10^{7}, 3$ 우.

\section{Paroxya Scudder}

\section{$P$. hoosieri Blatchley}

This species was first reported by Walker (1902a) as Paroxya floridana Smith. Specimens taken during the summer of 1938 were identified as $P$. hoosieri and later confirmed by James A. G. Rehn. The identification as $P$. floridana was later corrected to $P$. hoosieri by Walker and Urquhart (1940).

This species appears to be limited to marsh areas close to Lake Erie.

Kingsville: Aug. 9, 1901, $7 \sigma^{7} \sigma^{7}, 5$ 우 우, Walker. Point Pelee: Aug. 28, 1938, $10^{7}$. ARner: Aug. 12, $10^{7}, 2$ $\%$; Aug. 19, $130^{7} o^{7}, 14 \%$ $q 1$ nymph; Sept. 5,1 \% ; 1938 . 


\section{Literature Cited}

ANDER, K. 1939. Systematische Einteilung und Phylogenie der Ensiferen (Saltatoria) auf Grund von vergleichend-anatomischen Untersuchungen. Verhandl. 7. Internationalen Kongress für Entomologie in Berlin 1938. 1939a. Vergleichend-anatomische und phylogenetische Studien über die Ensifera (Saltatoria). Lund 1939, Berlingska Boktryckeriet. Opuscula Entomologica, Supp. 2, Lund.

Blatchley, W. S. 1920. The Orthoptera of North-eastern America. Indianapolis.

Carpentier, F. 1936. Le thorax et ses appendices chez les vrais et les faux Gryllotalpides. Mem. Mus. R. Hist. Nat. Belg. 2me ser. fasc. 4. Bruxelles.

Fletcher, J. 1892. The northern mole cricket. Can. Ent., 24:23-25.

Fulton, B. B. 1926. Geographical variation in the nigricornis group of Oecanthus (Orthoptera). Iowa St. Col. Jour. Sci., 1:43-62.

Hebard, M. 1925. The Orthoptera of South Dakota. Proc. Acad. Nat. Sci. Phil., 77:33-62.

1934. The Dermaptera and Orthoptera of Illinois. Ill. Nat. Hist. Surv. Bull. 20:125-279.

Hubbell, T. H. 1936. A monographic revision of the genus Ceuthophilus. Univ. Fla. Pub. Biol. Sci. Ser., 2:1-551.

KaRnY, H. H. 1910. (Orthoptera s.s.). In: Schultze. Zoologische und anthropologische Ergebnisse einer Forschungsreise im westlichen und zentralen Südafrika, IV, (Jenaische Denkschriften XVI):35-90.

KIRBY, W. F. 1910. A synonymic catalogue of Orthoptera-vol. 3. Orthoptera Saltatoria, Pt. 2 (Locustidae vel Acridiidae), pp. vii and 674. London.

Merriam, C. H. 1893. The geographical distribution of life in North America, with special reference to the Mammalia. Proc. Biol. Soc., Wash., 7:1-64. 1894. Laws of temperature control of the geographical distribution of terrestrial animals and plants. Nat. Geogr. Mag., 6:229-238.

1898. Life zones and crop zones of the United States. Bull. U.S. Dept. Agric., Div. Biol. Surv., No. 10:1-79.

Putnam, D. F. and Chapman, L. J. 1938. The climate of southern Ontario. Sci. Agri., 18:401-446.

Rehn, J. A. G. and Hebard, M. 1916. Studies in the Dermaptera and Orthoptera of the Coastal Plain and Piedmont region of the southeastern United States. Proc. Acad. Nat. Sci. Phil., 68:296-298.

Tномаs, C. 1872. Notes on the Saltatorial Orthoptera of the Rocky Mountain regions. Prelim. Rep. U.S. Geol. Surv. of Montana and portions of Adjacent Terr., 1871, 423-466.

UrquHART, F. A. 1937. Some notes on the sand cricket (Tricactylus apicalis Say) in Ontario. Can. Field-Nat., 51:28-29.

1939. The American locust (Schistocerca americana Drury, Orthoptera) in Ontario. Can. Field-Nat., 53:24-25.

1940. Notes on the Ontario species of Scudderia (Orthoptera, Ensifera). Can. Field-Nat., 54:102-106.

1940a. Further notes on the sand cricket, Tridactylus apicalis Say. Can. Field-Nat., 54:106.

1941. The species of Nemobius (Orthoptera, Ensifera) in Ontario. Can. Field-Nat., 55: 80-82. 
Walker, E. M. 1898. Notes on some Ontario Acridiidae. Can. Ent., 30:122$126 ; 258-263$.

1899. Same. Can. Ent., 30:29-36.

1901. Same. Can. Ent., 30:29-36.

1902. The Canadian species of Trimerotropis. Can. Ent., 34:11.

1902a. A preliminary list of Acridiidae of Ontario. Can Ent., 34:251258.

1904. The crickets of Ontario. Can. Ent., 36:142-144; 181-188; 249-255. 1904a. Notes on the Locustidae of Ontario. Can. Ent., 36:325-330; 337-341.

1905. Same. Can. Ent., 37:34-38; 113-119.

1912. The Blattidae of Ontario. Can. Ent., 44:171-172.

Walker, E. M. and Urquhart, F. A. 1940. New records and notes of Orthoptera in Ontario. Can. Ent., 72:15-19.

Zeuner, F. E. 1939. Fossil Orthoptera Ensifera. London.

1928. Opinions rendered by the International Commission on Zoological Nomenclature. Opinions 98 to 104. Smith. Misc. Coll., 73, (5): 28 pp. 


\section{CONTRIBUTIONS \\ OF THE \\ ROYAL ONTARIO MUSEUM OF ZOOLOGY}

This series contains reports of Museum studies, including faunal surveys. Except where otherwise stated the price is twenty-five cents a copy.

1. A Faunal Survey of the Lake Nipigon Region, Ontario, by J. R. Dymond, L. L. Snyder and E. B. S. Logier. 58 pages.

2. A Faunal Survey of the Lake Abitibi Region, Ontario, by the staff of the Royal Ontario Museum of Zoology. 46 pages.

3. A Faunal Investigation of King Township, York County, Ontario, by L. L. Snyder and E. B. S. Logier. 42 pages (out of print).

4. A Faunal Investigation of Long Point and Vicinity, Norfolk County, Ontario, by L. L. Snyder and E. B. S. Logier. 120 pages (out of print).

5. Some Account of the Amphibians and Reptiles of British Columbia, by E. B. S. Logier. 26 pages (out of print).

6. A Study of the Sharp-tailed Grouse, by L. L. Snyder. 66 pages.

7. The Passenger Pigeon in Ontario, by Margaret H. Mitchell. Records of the history of the now extinct wild pigeon (Ectopistes migratorius) in Ontario. Paper, \$1.00. Cloth, \$1.50. 181 pages.

8. The Distribution of Breeding Birds in Ontario, by James L. Baillie, Jr., and Paul Harrington. 134 pages.

9. Some Freshwater Fishes of British Columbia, by J. R. Dymond. 14 pages.

10. The Birds of the Lake St. Martin Region, Manitoba, by T. M. Shortt and Sam Waller. 51 pages.

11. Baird's Sparrow, by B. W. Cartwright, T. M. Shortt and R. D. Harris. 44 pages.

12. Ontario and its Avifauna, by L. L. Snyder, and The Museum's Bird Collection, by J. L. Baillie. 14 pages.

13. Birds of Algonquin Provincial Park, Ontario, by D. A. MacLulich. 47 pages.

14. A Faunal Investigation of Western Rainy River District, Ontario, by L. L. Snyder. 57 pages.

15. The Fishes of the Ottawa Region, by J. R. Dymond. 43 pages.

16. The Birds of the Vicinity of Lake Nipissing, Ontario, by W. E. Ricker and C. H. D. Clarke. 25 pages.

17. The Summer Birds of Yakutat Bay, Alaska, by T. M. Shortt. 30 pages.

18. History of the Royal Ontario Museum of Zoology, by J. R. Dymond. 52 pages.

19. A Faunal Investigation of Prince Edward County, Ontario, by L. L. Snyder, E. B. S. Logier, T. B. Kurata, F. A. Urquhart, and J. F. Brimley. 123 pages.

20. The Blattaria and Orthoptera of Essex County, Ontario, by F. A. Urquhart. 32 pages. 
(3) $2 \zeta 1$ 9063 1 




